雨水浸透施設の土壌浄化と地下水への影響

Water Purification and Contamination for Rainfall Infiltration

$\begin{array}{crllll}\text { 東京都土木技術研究所 } \bigcirc \text { 正 } & \text { 員 } & \text { 小 } & \text { 進 } \\ \text { 同 上 } & \text { 正 } & \text { 員 } & \text { 和 泉 清 } \\ \text { 東京都公害研究所 } & & & \text { 小野塚春吉 }\end{array}$

1.はじめに

東京都建設局では, 総合治水事業の一環として, 流出抑制のための雨水浸透施設を試験的に神田川, 目黒 川, 野川, 残堀川, 鶴見川の各流域の公園と車道の既設集水ますに対して, 下水管と分流する構造で, 合計 92 力所設置した。

雨水浸透施設山, 大別して, 縦型 (浸透井, 直径 $200 \mathrm{~mm}$, 梁さ $5 \sim 10 \mathrm{~m}$ ) と横型 (浸透卜レンチ, 砕石量 $5 \mathrm{~m}^{8}$ ないし $2.4 \mathrm{~m}^{8}$ ) とがあるが（図 1 ）, 今までの調査の中で, 浸透能や水質の面から縦型上りる横型の方 が有力であるととが判明している。

とてろで, 雨水浸透施設については, しばしば地下水かん養が強調されるが, 反面, 地下水への水質的影 響についてはあまり触れられていない。しかしながら, 地下水污染の恐れは多分にあり,しかすその詳細は 全く不明といってょい状況にある。

そてで, 縦型と横型の浸透施設につけて, 雨水に上る污濁負荷の機構を解明するために, 詳細な水質調査 を行なった。また，水質活染の防止のためのフィルタ一開発る同時に行なった。

とてでは，そらした調査結果を示し，報告としたい。

\title{
2. 特殊フィルターと水質
}

\section{$2-1$ 特殊フィルター}

都市部における雨水は，さまざまな污染源により污染されており，特に路面排水は路上の土砂をはじめ， 降下ばレじん, 排気ガス等により強く污染されている。したがって, 直接, 地下に流入させる構造の雨水浸 透施設は，地下水污染だけでなく，浸透部での目詰りにょる維持管理上の問題も生じてくる。

そのためには雨水をフィルターに通して, 浮遊物等を除去する構造が必要となる。東京都土木技術研究所

たて型標準搆造

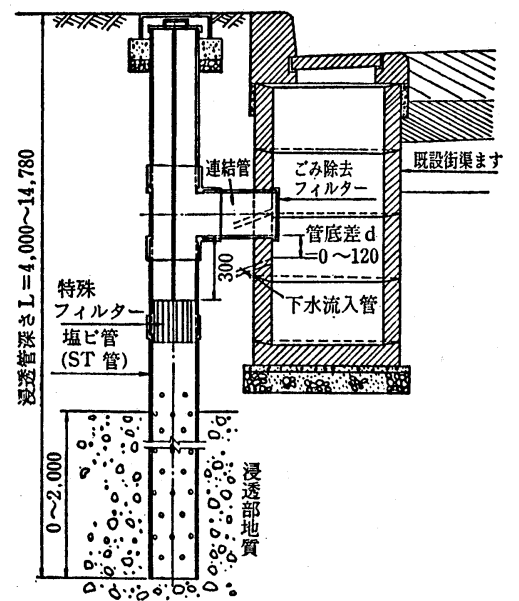

よこ型標淮棤造

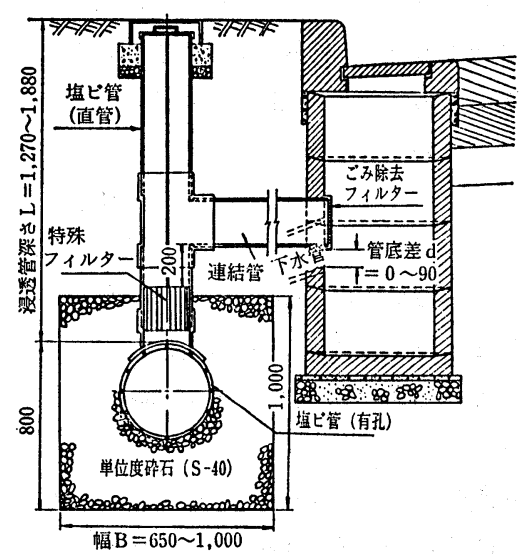

図 1 「綎型」「横型」標準構造図 
では,こらした機能をるつ“特殊フィルター”等も開発した。

実用化された特殊フィルターには, 大別して 3 種類のすのがあ る(図 2 )。I 型は, 円筒形のケースの中に, ポリェステル製の 不織布をポリエチレン製のネットと互層状にしたるので, 主とし て、葉のような粗大なゴミを除去するととを目的とする。II型は 肉厚のある円筒形ケースの中に, ポリ塩化ビニリデン製のマット を重ね，下層には活性炭の袋を敷いたるので, 目詰りの軽減と水 質の向上をはかったものである。而型は,フィルター面を円筒状 とし, 面積の拡大をはかり, さらに内部には活性炭を充てんし, ょり, 目詰りの軽減, 透水性及び水質の向上をめさしたものであ る。

これらについて, 水質との関連を調査した。また, 下水管と分 流管との管底差の水質への影響も調べた。

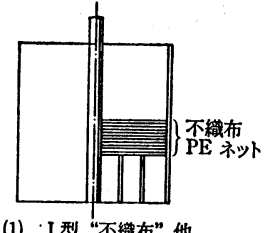

(1) II 型“不織布”他

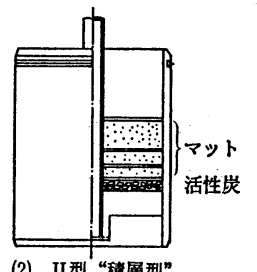

(2) II 型 “栍層型”

図2特殊フィルター構造図
$2-2$ 分析方法

92 地点中, 58 地点を選び, 降雨直後の, 街渠ま

す及び特殊フィルタ一通過後の雨水を採取し, 主 として「工場排水試験方法」(JISK0102-1981) に準拠して, 分析を行なった。

分析項目としては, 水質は, PH, S S, BOD,

COD, 大腸菌群数, 油分, 鉄, マンガン, 亜鉛,

クロム, 銅, ヒ素, カドミウム, 水銀, 鉊, フッ

素, シアン, 有機リン, フェノール, 硝酸性窒素,

\begin{tabular}{r|rrrrr}
\hline & 街まます & I 型 & I I 型 & III型 \\
\hline B O D & 59 & 34 & 10 & 8 \\
C O D & 282 & 116 & 8 & 26 \\
S S & 1700 & 540 & 86 & 147 \\
油 分 & 4 & 14 & 1 & - \\
\multicolumn{1}{c|}{ 鉄 } & 130 & 17 & 7.4 & 0.4 \\
\hline 地点数 & 3 & 38 & 11 & 6 \\
\hline
\end{tabular}

表 1 特殊フィルターと水質 (単位 $\mathrm{mg} / \mathrm{l}$ )

有機塩素化合物, 陰イオン界面活性剂であり, 底質は,

油分, 鉄, マンカン, 亜鉛, クロム, 銅, 七素, カド ミウム, 水銀, 鉛である。

$2-3$ 結果と考察

特殊フィルタ一通過後の流入水の水質の全般的な特 徴としては, 鉄, マンカン, 亜鉛がやや高く, 概ね, 河川の水質に近いものであった。底質（沈澱物）は， 既設集水ます内の底質と同様のものであり, 重金属濃 度の高い土堙である。乙れらは, 水には不溶で, ただ $(\mathbf{m g} / 1)$ ちに影響はないるのの, 注意を要する。

特殊フィルターと水質の関係を表 1 亿示す。

I 型, II 型, III 型の順に, 水質の向上が見られる。 III 型の場合, B O D 值が $2 \mathrm{p} \mathrm{pm}$ 以下を示す地点が 2 力 所あった。水質污染が問題となる地点については, こ れらの使用にょって, ある程度, 污染が避けられると 考えられる。

下水管と分流管との管底差は，初期雨水を除外して，

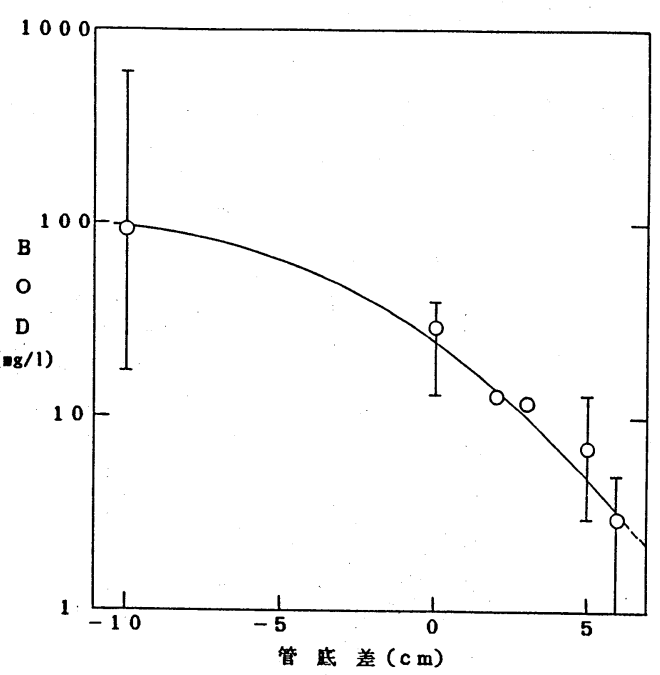

図 3 管底差と B O D 毎時 $10 \mathrm{~mm}$ 以上の降雨のみを, 浸透させるために, 標準 構造では $3 \mathrm{~cm}$ となっている。そてで，下水管と分流管 との管底差と水質との関係をみたのが, 図 3 である。 
管底差が増加するにつれて，BOD值の低下が見られる。管底差が $6 \mathrm{~cm}$ 以上では, 水質の向上は止まる。 また，管底差が $3 \mathrm{~cm}$ 付近で B O D 值が $10 \mathrm{ppm}$ 程度であるととがわかる。

すなわち, 標準構造では，BＯD值で $10 \mathrm{ppm}$ 程度が期待される。

水質は, 一般には, 雨水浸透施設の周辺環境に強く依存するが, 特に, ゴミ処理場やゴミ集配所, 建設現 場,カンリンスタンド等が污染源となっている。

\section{3. 極微量有機物分析}

\section{$3-1$ 地下水への影響}

たて型の場合, 雨水を直接, 帯水層に注入させるため, 水質調査を行い, 地下水への影響を調べてとが 必要である。今までのとてろ, 重金属, 特に水銀, カドミゥム, 鉊に関しては, 仮りに飲用しても，人体に 著しい障害を及汪す任どの濃度は含まれていないが, 多環芳香族等の炭化水素については, 現在, 全く不明 である。

そこで, いかなる炭化水素が, どの程度含まれているか, たて型について調査した。定量的には, 多環芳 香族の代表であるベンゾ(a)ピレンを分析し, 定性的には，分 子量 400 以下の炭化水素を同定した。

表 3 極徽量炭化水素のG C-MS 分析結果

$3-2$ 実験方法

交通量の多い幹線道路（環状 6 号,同 7 号,同 8 号都道 246 号線）に設置されている5 本の縦型について, 路面堆積物 （粉じん）, 街渠ます内沈澱物, 浸透管内水, 同沈澱物（底 泥)を採取し, 化学分析した。

ペンゾ(a)ピレンについては, 薄層クロマトグラフィを用い て, 同定, 定量した（定量限界 $30 \mathrm{ppm}$ )。

また, 炭化水素につんては, ガスクロマトグラフィ”質量 分析器を使用した。

$3-3$ 結果と考察

ベンゾ(a)ピレンの定量結果を表 2 亿示す。路面堆積物, 街 渠ます内沈暂物，浸透管内沈澱物の中に，それぞれ〜 1940 $320 \sim 2820,250 \sim 1600 \mathrm{ng} / \mathrm{g}$, さらに, No. 5 地点では 浸透管内水飞 $260 \mathrm{ng} / \mathrm{g}$ 含玉れていた。

污染経路を断定することはできないが, ベンン゙(a)ピレンは 大気中の粉じんないしは自動車の排気ガス中に多く含まれて らるので, 路面堆積物に付着し,それが雨水により街渠ます さらには浸透管内に流入した可能性がある。

\begin{tabular}{|c|c|}
\hline 分子量 & 成 分 \\
\hline $\begin{array}{lll}1 & 0 & 6 \\
1 & 2 & 0 \\
1 & 2 & 0 \\
1 & 2 & 8 \\
1 & 3 & 2 \\
1 & 3 & 4 \\
1 & 6 & 4 \\
1 & 6 & 6 \\
1 & 9 & 8 \\
2 & 1 & 0 \\
2 & 1 & 2 \\
2 & 2 & 0 \\
2 & 2 & 0 \\
2 & 2 & 6 \\
2 & 4 & 0 \\
2 & 5 & 4 \\
2 & 6 & 8 \\
2 & 7 & 8 \\
2 & 8 & 2 \\
2 & 9 & 6 \\
3 & 1 & 0 \\
3 & 2 & 4 \\
3 & 3 & 8 \\
3 & 6 & 6 \\
3 & 9 & 0\end{array}$ & 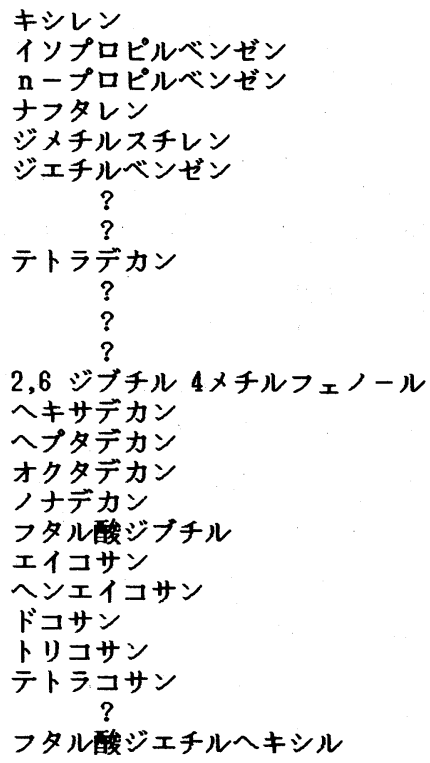 \\
\hline
\end{tabular}

ところで, ベンゾ(a)ピレンが他の地点で検出されず，No. 5

表 2 ベンゾ (a) ピレンの分析結果 (単位 $\mathrm{ng} / \mathrm{g}$ )

\begin{tabular}{|c|c|c|c|c|c|}
\hline 種類 地点 & 1 & 2 & 3 & 4 & 5 \\
\hline 路面堆皘物 & N D & 1220 & 1150 & 1940 & * \\
\hline 街きょます内沈殷物 & 710 & 320 & 2820 & 1930 & * \\
\hline 浸透管内沈殿物 & 1210 & 460 & 1600 & 250 & $*$ \\
\hline 浸透管内水 & N D & N D & N D & N D & 260 \\
\hline
\end{tabular}

*ピーク分離不充分のため定量できず。 
地点でのみ検出された原因は，上記の污染経路だけでは考えられない。N.1４地点とも大気の污染状況も 自動車の交通量も同規模であり,むしろN. 5 地点（府中市多磨町）の方が交通量が少なく污染されにくい状 況にあった。しかしながら同地点には, 某事業所が隣接し, 常に洗浄水が街渠ます内に流入し,さらに下 水管とたて型の分流管との管底差がー10cmであり, 污水が下水には流れず, 全量, たて型の浸透管に流入す る構造になっている。とのととが，N５地点が污染された一因であるかもしれない。

したがって, 雨水浸透施設には, 下水等の污水が流入しない構造とし,さらに周辺環境をる考慮に入れる 必要がある。

次に，No. 地点における極微量炭化水素のガスクロマトクラフィ・質量分析の結果を表 3 に示す。No.4 地 点（世田谷区船橋 1 丁目）は環状 8 号線に面している。

この結果, 浸透管内水には, 極微量の, キシレン, プロピルペンゼン等の芳香族炭化水素, 炭素数が14か ら 24 での脂肪族, 2 環のナフタリン, フタル酸類, シブチルメチルフェノール(酸化防止剤) 等の炭化水 素が含まれているととが判明した。

これらの定量ならびに污染経路の究明が, 今後の課題である。

\section{4. 土壤浄化}

\section{4-1 地下水汃養}

雨水浸透施設は, 流出抑制のみならず, 地下水かん盖の点 です注目されている。特に拡水型に分類される浸透トレンチ (横型)は, 土壤净化にょり水質面でも問題ないとされてい る。

しかし, 流出抑制施設の土堙净化の報告例はなく, 実態は 不明である。そてで, 土中水分計に併設した土䤑溶液採水器

（図 4 ）を用いて，浸透水を採取し，化学分析を行った。

4-2 実験方法

タンクローリー車（10トン）を使用して, 浸透トレンチに 毎分 $100 \ell て ゙$, 約 100 分間, 河川水を連続注入する。注入終 了時に, 西らかじめ土中水分計と併設した土镶溶液採水器に 上り，浸透水を採取する。浸透状況は土中水分計に上り確認 する(図 5 )。対照試料として, 注入前に土湲水を採取した。 注入は合計 3 回行なった。

水質分析項目は, 採水量の制限に上り, 電気伝導度, ナ卜 リウム, カルシウム, クロム, マンガン, 鉄, ニッケル, 銅 亜鉊, 鉛に限った。

\section{4-3 結果と考察}

3 回の注入試験の結果は, 全て同様の傾向を示した。結果 の一部を表 4 亿示す。

電気伝導度は, 一般飞, 水中に溶解するカルシウム, マク ネシウム,ナトリウム, カリウム等の金属イオンと炭酸水素 硫酸, 塩素等の陰イオンの濃度を反映する。したがって, 浸

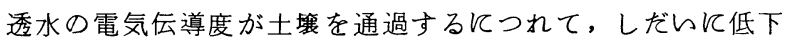
してゅく傾向は, 上記のイオンが土壤に吸着されてゅく過程 を示している。同様の傾向は, ナトリウムと銅の各イオンに

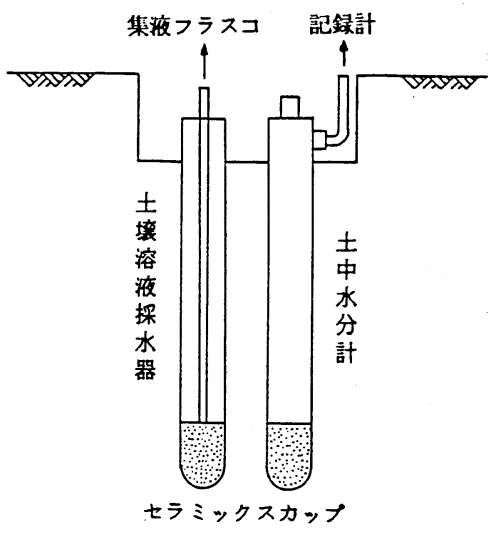

図 4 土壌溶液採水器

注入水

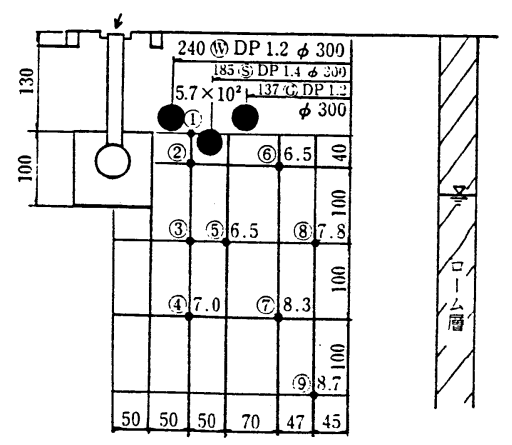

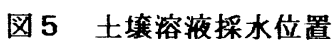


も見られる。図 6 には, 電気伝導度とナトリゥムイオンのトレンチからの距離に対する変化を示している。 距離の増加ととるに指数関数的に減少している。図中の破線は付近の井戸の電気伝導度 $(200 \mu \mathrm{S} / \mathrm{cm})$ を表わ している。約 $170 \mathrm{~cm} て ゙$ 井戸水と同等の水質に変化しているととがわかる。

とてろが,カルシゥム, マンガン, 鉄, 亜鉛に関しては,乙らした減少傾向は見られず,むしろ, 注入水

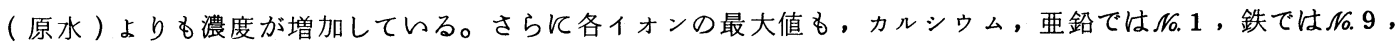
マンカンではN.2 と, 一定していない。

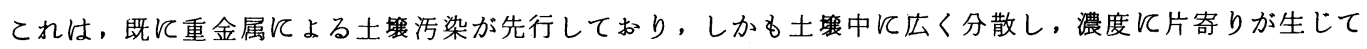
らるととを意味する。それが，注水により，溶出したるのと考えるととがでをる。

すなわち, 浸透トレンチに おいて, 雨水に溶解するナト リウム等のイオンは土壌中に 吸着され, 指数関数的な减少 を示すが, カルシウム, マン カン, 鉄, 垔鉊といった金属 イオンは, 先行する土裹污染 (バックグランドを含めて) により, 逆に溶出し, 水質を 悪化させる。

なお,クロム、ニッケル， 鉛については, いずれる検出

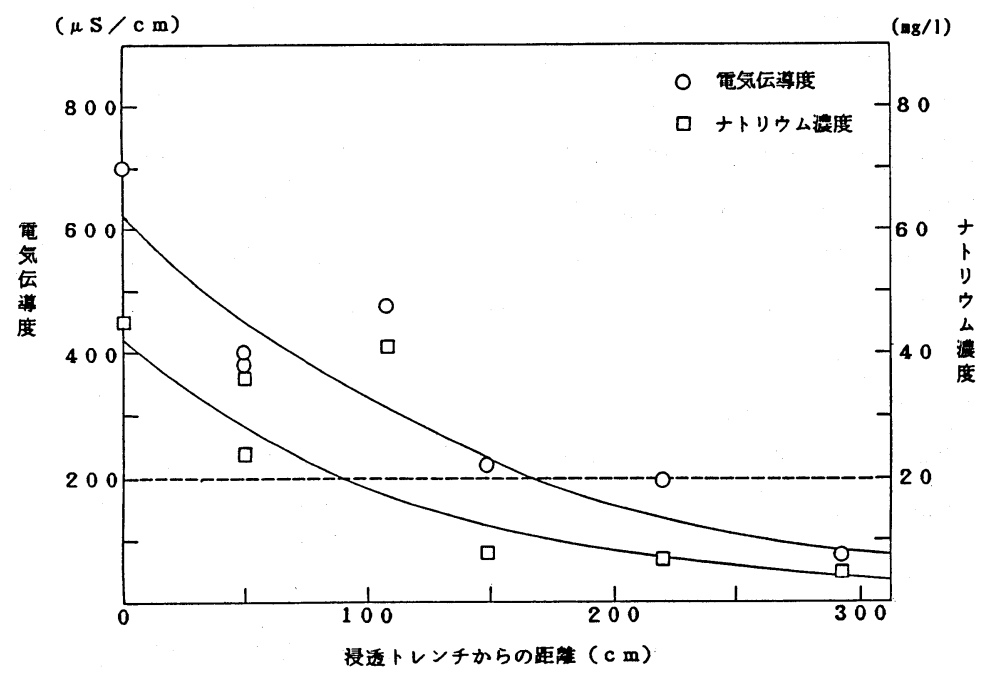

図 6 電気伝導度とナトリウムイオン浱度

表 4 土壌溶渡の水質 (溶解分。単位mg/l)

\begin{tabular}{|c|c|c|c|c|c|c|c|}
\hline 地点 項目 & $\mathrm{N} \mathrm{a}$ & $\mathrm{C}$ a & $\mathrm{Fe}$ & $\mathrm{Zn}$ & $\mathrm{Mn}$ & $\mathrm{C} \mathrm{u}$ & $\begin{array}{c}\text { 電気伤導度 } \\
(\mu \mathrm{S} / \mathrm{m})\end{array}$ \\
\hline 原 水 & 46.1 & 25 & 0.5 & 0.07 & $0 . \quad 02$ & 0.05 & 700 \\
\hline 1 & 23.8 & 80 & 0.1 & 0.09 & 0.03 & 0.03 & 405 \\
\hline 2 & 36.1 & 50 & 1. 1 & N D & 1. 84 & 0.01 & 380 \\
\hline 4 & 7. 9 & 17 & 1. 2 & 0.01 & 0.43 & N D & 220 \\
\hline 5 & 40.6 & 50 & N D & 0.04 & 0.70 & 0.01 & 475 \\
\hline 7 & 6. 9 & 12 & 2. 0 & N D & 0. 31 & N D & 195 \\
\hline 9 & 4. 7 & 10 & 2. 2 & 0.02 & 0.39 & N D & 75 \\
\hline
\end{tabular}

表 5 付近の井戸の水質（杉並区清水 1 丁目）

\begin{tabular}{|c|c|c|c|c|c|c|c|}
\hline 採取日 & 井戸数 & $\begin{array}{l}\text { 電気伀導度 } \\
(\mu \mathrm{s} / \mathrm{m})\end{array}$ & $\begin{array}{l}\text { 窒素 } \\
(\text { (ng/1) }\end{array}$ & $\begin{array}{r}\begin{array}{c}\text { 塩素 } \\
(\mathrm{gg} / 1)\end{array} \\
\end{array}$ & $\begin{array}{c}\text { 鉄 } \\
(18 / 1)\end{array}$ & 硬度 & $\begin{array}{r}C O D \\
(18 / 1)\end{array}$ \\
\hline $82.1 \sim 2$ & 36 & 214 & 8. 7 & 28. 6 & $<0 . \quad 1$ & 65. 1 & 1. 4 \\
\hline 83.11 .28 & 30 & - & 6. 5 & 19. 2 & $<0.7$ & 0.07 & 70.3 \\
\hline 84.3 .16 & 5 & - & 4. 4 & 23.9 & $<0.6$ & 0.02 & 63.6 \\
\hline
\end{tabular}


されなかった。

\section{5. 結論}

（1）道路雨水の水質は, マンカン, 鉄, 亜鉊がやや高く, 都市河川水の水質に類似している。沈澱物は重金 属を含む土裹が大部分である。また水質は周辺環境の影響に鋭敏である。

（2）特殊フィルターは，水質向上がはかれるので，污染環境に対してある程度有効である。

（3）分流構造の雨水浸透施設では，下水管と分流管との管底差の増加により，6 cmまでは水質が向上し，3 cm以上で B O D 值が $10 \mathrm{p} \mathrm{pm}$ 程度になる。

(4) 多環芳香族のベンゾ(a)ピレンが某事業所に隣接する浸透井（縦型）上り検出されたが，原因の一つの 可能性として同事業所の洗浄水が流入する構造にあると考えられる。污水が流入しないよらに, 構造と周辺 環境に留意する必要がある。

（5）浸透井の水質には，路面堆積物等から流入したと考えられる極微量の種々の炭化水素が含まれており， 今後とも監視してゅかねばならない。

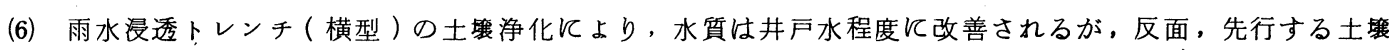
污染に上り,カルシウム, マンカン, 鉄, 亜鉛等の金属イオンは溶出し, 水質を悪化させている。

\section{【謝辞】}

なお, 本研究にあたり, 東京都公害研究所の小山功, 菅邦子, 泉川碩雄の各氏, をた東京都土木技術研究 所の山本弥四郎，土屋十固，柳澤満の各氏に多大な御協力をいただいたととを記し，ここに謝意を表したい。

\section{参考文献}

（1）小川進，山本弥四郎「雨水漫透ますの水質調査」第29回水理講演会論文集（1984）

（2）和泉清他「雨水浸透ますの浸透能・水質等調査報告結果」昭和59年度東京都土木技術研究所年報 (1984)

\section{【付記】}

現在, 計画されている雨水浸透施設は, 上記の結論等を考虑して, 横型( 浸透トレンチ)を主力にする， 管底差を $3 \mathrm{~cm}$ にる, 周辺環境の㯖い地点は不適地とする, 等の改善がもりてまれている。 